\title{
Foucault JA TIETEELLISEN TIEDON ULOTTUVUUDET
}

Markku Koivusalo esittää Foucault'n Tiedon arkeologiaa (TA) esittelevässä kirjoituksessaan "Ajattelun hajautunut aineellisuus" (T\&E 1/2006) tärkeitä täsmennyksiä siihen käsitteelliseen erotteluun, jonka Foucault teki tiedon kahden tyypin välillä ranskan kielen termien savoir ja connaissance avulla. Jos aiomme soveltaa tätä erottelua edelleen, meidän on tietenkin oltava perillä siitä, miten Foucault sitä käytti. On myös olennaista, että suomennoksissa käytetään termejä, jotka tuovat erottelun perustan esiin. "Tieto" (savoir) vs. "tietämys" (connaissance) on erinomainen ratkaisu.

Olen kuitenkin erityisen kiinnostunut erottelua koskevista jatkokysymyksistä: miten erottelu vastaa tieteellisessä ymmärryksessä esiintyviä erilaisia tiedon tyyppejä? Ja yleisemmin: voimmeko käyttää Foucault'n erotteluja hyväksemme koettaessamme ymmärtää muutoksia, joita on tapahtunut tieteen yhteiskunnallisessa asemassa viime aikoina - jopa viime vuosina?

Olen ryhtynyt luonnehtimaan erottelua sanonnoilla "asiantiloja [tapahtumakulkuja] koskeva tieto" (savoir) vs. "kokonaisuudeksi jäsentynyt tieto" (connaissance) ${ }^{1}$ Erottelun soveltuvuus tieteelliseen tietoon tuntuu intuitiivisesti selvältä: empiirinen tutkimus selvittää asiantiloja [tapahtumakulkuja], ja niitä koskeva tieto saa merkityksensä käsitteellis-teoreettisten tulkintakehysten välityksellä. Erottelun voi tunnistaa myös Foucault'n omissa empiriaan perustuvissa teoksissa. Merkitykselliset tapahtumakulut ovat niissä korostuneessa asemassa, esimerkiksi seuraavasti: Hulluuden historiassa olennaisen tapahtumakulun ("tosiasian") muo- dostaa eristyslaitosten äkillinen yleistyminen klassisen kauden alussa $1600-$ luvulla; ${ }^{2} \mathrm{Kli}$ nikan synnyssä olennaisen tapahtumakulun muodostaa patologian vakiintuminen lääketieteen tutkimuskäytännöksi. ${ }^{3}$

Molemmat esimerkkitapaukset näyttäytyvät merkityksellisinä tapahtumakulkuina nimenomaan Foucault'n analyyttisen optiikan tunnistamina. Molemmat ovat peräisin yhteiskunnallisten käytäntöjen muutoksista ja ilmentävät tällaisia muutoksia sekä niitä koskeneita näkemyksiä. Ne ovat aivan liian monitahoisia ja -tasoisia kelvatakseen perinteisen historiankirjoituksen "faktoiksi". Foucault rekonstruoi näistä monitasoisista tapahtumakuluista ja merkityksenannoista kokonaisnäkemyksen.

Toisin sanoen ne tiedon ulottuvuudet, joita Foucault analysoi Hulluuden historiassa ja Klinikan synnyssä, kietoutuvat tiiviisti ja monitasoisesti yhteiskunnallisten käytäntöjen muutokseen. Tässä kiteytyy Foucault'n radikalismin ydin. Tieto kasvaa esiin ihmisten aineellisista toimista ja saa yhteiskunnallisen muodon, tiiviisti kietoutuneena monitasoisiin tulkinnallisiin käytäntöihin.

Foucault tukeutui tietoa koskevissa näkemyksissään paljolti Nietzscheen. "Brasilian luennoissaan" "hän esitti näkemyksensä lähtökohdaksi Nietzschen toteamuksen, että inhimillisellä tiedolla ei ole ylimaallisia takeita. Toteamuksen ydin ei liity epistemologiaan, tiedon hankkimisen yleisiin periaatteisiin, vaan inhimillisen subjektin asemaan maailmassa. Nietzsche asetti kyseenalaisiksi joukon siihenastisia itsestään selvyyksiä: Onko ihminen todellakin olio, jolle on mahdollista saada maailmasta täydellinen, oi- kea tieto? Onko inhimillisen tiedon oikeellisuuden takeeksi kuviteltavissa jokin muu mahti kuin Jumala? Onko "tieto" ylipäätään inhimillisen tiedon alkuperäinen tavoite; voiko "tieto" oikeuttaa itse itsensä?"

Kyseenalaistuksillaan Nietzsche sai aikaan katkoksen tietoa koskevassa käsityksessä; se, että hänen omana aikanaan juuri kukaan ei tätä tunnustanut, on toinen asia. Katkokseen viitaten Foucault toteaa, että se, mikä on hävinnyt, ei ole Jumala vaan ehyt ja suvereeni subjekti. ${ }^{6}$ Kun tiedon ennalta annettu subjekti häviää, tiedon oikeellisuuden ennalta annetut takeet häviävät myös. Ei ole mitään etukäteistä turvaa sille, millaisten "asiantilojen [tapahtumakulkujen]" kanssa tietoa tavoittelevat ihmiset joutuvat tekemisiin ja millaisiksi kokonaisuuksiksi he sitä jäsentävät. - Mutta sen jälkeen, kun ihmiset ovat kohdanneet asiantiloja [tapahtumakulkuja] ja alkaneet jäsentää niitä koskevaa tietoaan kokonaisuuksiksi, tämä kaikki on tietenkin todella olemassa; asialla ei ole mitään tekemistä konstruktionistisen sekasotkun kanssa.

Tiedon tiukka sidonnaisuus historiaan seuraa edellä sanotusta. Edellinen ratkaisee myös sen käsitteellisen dualismin, joka analyyttisessa perinteessä on konstruoitu faktojen ja tulkintakehysten keskinäissuhteeseen (ja jonka onttouden Donald Davidson osoitti analyyttisen filosofian omin argumentein 70luvun alussa). ${ }^{7}$ Sekä "asiantilat [tapahtumakulut]" että tietoa jäsentävät kokonaisuudet muuttuvat koko ajan keskinäisessä vuorovaikutuksessa ja vuorovaikutuksessa yhteiskunnallisiin käytäntöihin. Dynaamisuus on peräisin dis- 
kursiivisten käytäntöjen komplekseista ja moniulotteisista suhteista toisiinsa ja maailmaan. Tämä erottaa Foucault'n näkemyksen Kuhnin tieteellisten vallankumousten teoriasta, vaikka Kuhnin konstruoima "normaalitiede" vs. "paradigma" -asetelma on näennäisesti samankaltainen.

On oletettavissa, että tiedon tyyppien keskinäiset suhteet jäsentyvät eri tavoin eri aikakausina - ja ehkä myös eri kulttuureissa, mutta siitä tietomme ovat vajavaisia. Tiede on tavallaan "ortogonaalisella" akselilla tiedon ulottuvuuksiin nähden: se koettaa hankkia tietoa tosiasioista [tapahtumakuluista] ja määritellä näille mielekkään tulkintakehyksen samassa, moninaisiin käytäntöihin sitoutuneessa prosessissa. Tieteenalojen vakiintuminen on lajittelun ja karsinnan prosessi, johon sisältyy myös alojen suojelemisen "disiplinaarinen" ulottuvuus: "Tieteellisyyden alueelle kuuluvat vain tiettyjä rakentumislakeja noudattavat propositiot; jos väitteet eivät ole peräisin samasta systematiikasta, ne suljetaan alueen ulkopuolelle vaikka niillä olisikin sama merkitys, ne sanoisivat saman asian ja olisivat yhtä tosia" (TA, 237-8).

Mitä ovat ne muutokset tieteen asemassa, joihin Foucault'n käsitteistön soisi luovan valaistusta? - Tiivistäen (jopa hiukan karrikoiden): yhteiskunnallinen käytäntö, sekä yleisesti että erityisiksi käytännöiksi hajaantuneena, on kaikessa tutkimuksessa enenevässä määrin mukana. Tämä tuo mukanaan kaksi merkityksellistä muutoksen suuntaa: yhtäältä tieteellisen tietämisen luonne ja toisaalta tutkimusalojen disiplinäärinen luonne muuttuu.

Aloitan edellisestä. Tieteen- tutkimuksen piirissä vajaat 20 vuotta sitten tapahtunut "käytännöllinen käänne" on tässä yhteydessä merkityksellinen. Ian Hackingin Representing and Intervening ${ }^{8}$ on tunnustettu klassikko, joskin se on vielä kytköksissä filosofien huonoon tapaan arvioida tiedettä ensisijaisesti teorioina. Tutkimuskäytäntöjen empiirisen tutkimuksen uranuurtaja on Peter Galison, jonka projektin voi kiteyttää kysymykseen: millä tavoin tieteellisen tietämisen historialliset ehdot ovat muuttuneet tutkimuksen käytäntöjen muutosten seurauksena?? Eräs Galisonin havaintojen olennainen ulottuvuus liittyy tieteellisen tiedon subjektin valtavaan muutokseen: asiantilojen [tapahtumakulkujen] todentaminen ja tulkitseminen on nykyisin paljon suuremmassa määrin kollektiivista kuin koskaan aikaisemmin. Ei ole enää kysymys siitä, miten yhteiskunta vaikuttaa tieteeseen, vaan siitä, millaisia tietämisen maailmoja nykyisen tieteen tiedolliset käytännöt tuottavat. ${ }^{10}$

Uudenlaiset tutkimukselliset käytännöt ovat tuoneet tieteellisen tiedon piiriin odottamattomia asiantiloja, jotka ovat pakottaneet muuttamaan tietämisen ehtoja koskevia käsityksiä. Tunnettu ilmentymä on Heisenbergin epävarmuusperiaate. Periaate on itse asiassa mitä yksinkertaisin: kaiken havainnoinnin perustana on aineellinen interaktio havaitsijan ja havaitun välillä. Kun havainnointi kohdistuu riittävän pienen mittakaavan ilmiöihin, kuten yksittäisten alkeishiukkasten liikeratoihin, havaitsemisen akti muuttaa havaittua ilmiötä. Kyseessä on siis eräänlainen häiriintymisen universaali periaate, jonka fyysikko Vincent Icke kiteyttää aforismiin: "Jokai- sen vuorovaikutuksen hellyydellä on jokin alaraja; se on meidän maailmankaikkeutemme sisäänrakennettu rajoite, jota ei koskaan voida väistää, ei taidolla eikä huolenpidolla." Alkeishiukkaset muuttavat keskinäisissä vuorovaikutuksissaan toistensa luonteen täydellisesti. ${ }^{11}$

Havainnoinnin ja havaitun väistämätön interaktio on maailmassa vallitseva asiantila. Tämä asiantila ei merkitse ilmiöiden määräytyneisyyden (determinismin) yleisen periaatteen häviämistä, vaikka näin kuulemme usein esitettävän. Sen sijaan se osoittaa, että havaitseminen on aineellinen ja relaatioon perustuva prosessi. Havaitsemisen aktin seurauksena havaintotilanteisiin tulee uudentyyppinen määräytyneisyyden elementti, joka hävittää täydellisen ennustettavuuden, kun riittävän pieni mittakaava saavutetaan.

Toisen esimerkin, joka vasta on tunkeutumassa osaksi tieteellisen maailman tietämystä, tarjoaa kehitysbiologia. Molekylaariselle tasolle ulottuneet tutkimustekniikat (eli "molekyylibiologia") ovat osoittaneet, että yksilönkehitykseen vaikuttavat tekijät - geneettiset ja ympäristöperäiset - ovat keskenään erottamattomassa, hienopiirteisessä ja yksityiskohdissaan ennakoimattomassa vuorovaikutuksessa. Tämän seurauksena yksilönkehityksen ilmiöillä ei ole täsmällisesti spesifioituvia "riittäviä" ja "välttämättömiä" ehtoja, kuten selittämisen perinteinen ihanne edellyttää Erityisesti välttämättömien ehtojen häviäminen on tässä olennaista, riittävät ehdot hävisivät fysikaalisestakin tietämyksestä jo hyvän aikaa sitten. ${ }^{12}$ Täsmällisesti sanoen kysymys on siitä, että tietty lop- 
putulos voi syntyä useanlaisten vaikutusmekanismien välityksellä - mikään yksittäinen "syy" ei ole välttämätön tuloksen synnylle. Tämäkään ei merkitse ilmiöiden määräytyneisyyden häviämistä, joskin niiden täsmällinen ennustettavuus häviää. Tietynlaisille tapahtumakuluille voidaan tunnistaa niille mahdollisten kehityskulkujen joukko ("mahdollisuuksien avaruus" on käyttökelpoinen tekninen termi), mutta on mahdotonta nimetä suoraviivaisia kausaalisuhteita, jotka tekisivät tapahtumakulut ennustettaviksi ja hallittaviksi.

Tietämisen strategioille tämä merkitsee sitä, että yleisten lainmukaisuuksien etsimisen sijasta on koetettava hahmottaa tietyntyyppisten tilanteiden mahdollisuuksien avaruutta ja jäsentää tekijöitä, joiden vaikutuksesta erilaisten kehityskulkujen todennäköisyydet eriytyvät. Tätä voi luonnehtia kompleksisten systeemien tutkimuksen heuristiikaksi.

Miten nämä uutuudet liittyvät Foucault'n tiedenäkemykseen? - Välittömästi kahdella tavalla. Ensiksi on tavattoman jännittävä yksityiskohta, että Foucault'n innoittaja Nietzsche kykeni aforistisesti ennakoimaan tilanteen: maailma on järjestynyt sillä tavoin kuin inhimillinen tiede sen kykenee järjestämään vain siinä vähäisessä todellisuuden osassa, jonka kykenemme alistamaan järjestelmällisen havainnointimme kohteeksi. ${ }^{13}$ Toiseksi Foucault'n väsymätön diskursiivisten käytäntöjen merkityksen korostaminen saa ansaitsemansa painon. Käytännöt ovat rikkaampia kuin mikään teoria: käytäntöjen välityksellä tietynlaiset ilmiöt ilmaantuvat meille "asiantiloiksi [tapahtumakuluiksi]”, joiden todenmukaisuudesta voimme vakuuttua ja joille voimme antaa tulkintoja tiedollisten järjestelmiemme osana. Käytäntöjen ensisijaisuus ilmenee myös tiedon kahden tyypin jäsennyksessä; kuten Koivusalo toteaa, tieto (savoir) on käytännön kentillä muodostuva tietämyksen (connaissance) historiallinen ehto.

Sitten kysymykseen, miten tieteenalojen disiplinaarinen luonne on muuttunut. Tässä suhteessa tärkeä Foucault'n oivallus on, että tietävä subjekti on eettinen subjekti. Miksi juuri tietynlainen tieto on tietämisen arvoista? Tätä valintaa yksilö tuskin koskaan tekee, sen sijaan tiedon hankinnan käytännöt luovat ja tuottavat yksilöitä, jotka vievät tuota järjestelmää eteenpäin.

Kuten Foucault korosti, termillä "subjekti" on kaksinainen merkitys: subjekti on tekijä, mutta subjekti on myös oman subjekti-positionsa alamainen. ${ }^{14}$ Tieteellisen tiedon subjektin kohdalla tämä tarkoittaa sitä, että tiedollisten käytäntöjen ehdot muuntuvat subjektin sisäistämiksi ehdoiksi, vallan "mikrofysiikan" tutun dynamiikan tuloksena. - On tietenkin triviaalisti totta, että tieteellisen tiedon subjekti noudattaa tieteellisen tiedon hankinnan vakiintuneita sääntöjä: mikään muu ei ole hänelle mahdollista. Niin kauan kuin uskomme perinteisen tieteenfilosofian tapaan, että säännöt edustavat ennalta annettua kosmista rationaalisuutta, tämä itsestäänselvyys ei herätä minkäänlaisia tuntemuksia. Mutta kun lakkaamme uskomasta tähän, sääntöjen luonne, tieteenalojen disiplinaarisuus, muuttuu olennaiseksi kysymykseksi.

Termillä "yhteiskunnallinen käytäntö" ei ole mitään yksinkertaisesti havaittavissa ole- vaa vastinetta. Mitä siis tapahtuu, kun yhteiskunnalliset käytännöt ovat enenevässä määrin läsnä tieteellisen tutkimuksen maailmassa? Tämä juuri on kysymys, johon ei ole mitään yksinkertaista vastausta. Meidän tulisi esittää kohdennettuja jatkokysymyksiä, esimerkiksi: Mitä on "asiantila [tapahtumakulku]", kun tutkimuskohteena on vaikkapa "luova talous"? Mistä ovat peräisin tällaisia asiantiloja [tapahtumakulkuja] jäsentävät tiedon kokonaisuudet? Kykeneekö tutkimuskohteeseensa moninaisin institutionaalisin sitein kytkeytynyt tietävä subjekti asennoitumaan kriittisesti omaan subjekti-positioonsa? ${ }^{15}$

Tieteellisen subjektin uudenlaiset eettiset dilemmat asettavat eräänlaisen metodologisen haasteen; kutsukaamme sitä vaikkapa tarpeeksi kehittää uudenlaisia minätekniikoita. Täsmällisemmin sanoen: olisi kyettävä vahvistamaan tutkijoiden eettistä subjektiviteettia ja välttämään uudenlaiset työnjaot. Työnjaoille tarjoaa mallin vaikkapa se, miten "bioetiikka" on kasvanut uudeksi erityisalaksi ratkaisemaan biolääketieteen tutkijoiden puolesta tutkimuksen eettisiä ongelmia. Tulisi välttää erikoistuminen, madaltaa tieteenalojen välisiä rajoja, vahvistaa erilaisten tiedon lajien keskinäisiä yhteyksiä, ja niin edelleen.

Pohdintani tyyli on muuttumassa yhä normatiivisemmaksi. Mitä on tehtävissä? Muutamia vuosikymmeniä sitten ratkaisun tuntui tarjoavan Science for the People tyyppinen järjestäytyminen, mutta tämä mahdollisuus on haihtunut. "Citizen Science" on vanhan ideaalin lievennetty muoto, jota artikuloi tutki- 
musperinne "public understanding of science"; on vielä epäselvää, tuottaako se tuloksekseen muuta kuin uuden akateemisen erikoistumissuunnan. Tavallaan Ulrich Beckin teesi "yhteiskunta laboratoriona" jäsentää samaa tematiikkaa vastakkaisesta näkökulmasta kohdistaessaan huo- mion tieteellis-teknisen "edistyksen" ennakoimattomiin sivuseurauksiin. Beckin konsepti kuitenkin lähestyy kysymystä liian yleisluonteisen makrososiologisen prisman läpi tarjotakseen merkityksellisiä ratkaisuja käytännöllisiin dilemmoihin. (Sama ongelmaa vaivaa koko "riskiyhteiskunnan" konseptia).

Siis mitä? - En usko erehtyväni päätellessäni, että olemme tieteen yhteiskunnallisten sidosten muutoksen edessä enimmäkseen ymmällä. Tiedän, etten erehdy todetessani, että Foucault'n tiedenäkemys antaa aineksia ymmällä olon hälventämiseksi.

Yrjö Haila
1. Hyödyllisin englanninkielisestä kommentaarikirjallisuudesta löytämäni sekundaariesittely on: James D. Faubion, "Introduction", Essential Works of Foucault, Vol 2: XXVIII-XXX (The New Press, 1998).

2. History of Madness (Routledge 2006), 52: "The great hospitals, the houses of confinement, the civic and religious institutions for assistance and punishment, for charity and governmental assistance are a fact of the classical age, as universal as that age itself and contemporaneous with its birth."

3. The Birth of the Clinic (Tavistock 1973), Ch. 8: "Open up a few corpses."

4. "Truth and Juridical Forms", Essential Works, Vol. 3 (The New Press 2000).

5. Vrt. The Will to Power, par. 515: "Not to 'know' but to schematize - to impose upon chaos as much regularity and form as our practical needs require. [...] In the formation of reason, logic, the categories, it was need that was authoritative; [...] The categories are 'truths' only in the sense that they are conditions of life for us: as Euclidean space is a conditional 'truth'. (Between ourselves: since no one could maintain that there is any necessity for men to exist, reason, as well as Euclidean space, is a mere idiosyncrasy of a certain species of animal, and one among many ...)"

6. "It's not God that disappears but the subject in its unity and its sovereignty" (Truth and Juridical Forms, 10).

7. "On the very idea of a conceptual scheme", Inquiries into Truth and Interpretation. (Clarendon Press, 1984). Davidson luonnehti fakta-käsitekehysjaon "empirismin kolmanneksi dogmiksi" Quinen 1950-luvulla esittelemien empirismin kahden dogmin jatkoksi. Davidsonin veto oli omassa perinteessään radikaali melkeinpä foucault'laisessa mielessä: hän oivalsi, että empirismi tarvitsi käsitteellisten kehysten ja faktojen dualismia saadakseen tiedon universaalisuuden idean uskottavaksi.

8. Cambridge University Press, 1983.

9. Galisonin keskeiset teokset ovat How Experiments End (University of Chicago Press, 1987) ja Image and Logic. A Material Culture of Microphysics (University of Chicago Press, 1997). Galisonin työt ovat erityisen vaikuttavia siksi, että niiden kohteena on kovimmista kovin luonnontiede, kokeellinen fysiikka.

10. Rinnastukseksi sopii Howard Beckerin klassikko Art Worlds University of California Press, 1982), joka tuotti nykytaiteen ymmärtämiseen vastaavanlaisen murroksen. On oireellista, että monet tieteentutkijat ovat metodologisesti kiinnittyneet Beckerin tavoin symboliseen interaktionismiin analysoidessaan tieteen maailmoissa vallitsevia symbolisia jäsennyksiä.

11. The Force of Symmetry (Cambridge University Press, 1995). Nimenomaan käytännölliseltä kannalta periaate on yksinkertainen. Platonistisen tietoteorian se on saattanut suuren hämmennyksen valtaan, mutta tästä seikasta ei sovi moittia alkeishiukkasia.

12. Isabelle Stengers, Power and Invention. Situating Science (University of Minnesota Press, 1997).

13. Vrt. viite 5.

14. "The Subject and Power", Essential Works Vol. 3, 326-348 (The New Press, 2000).

15. Moni muukin Sitran rahoittama tutkimusprojekti sopisi tähän yhteyteen esimerkiksi. Myös Opetusministeriön rahoittamien uusien tutkijakoulujen teemaluettelo on valaiseva. 